\title{
In vitro probiotic characterization of high GABA producing strain Lactobacilluas brevis DSM 32386 isolated from traditional "wild" Alpine cheese
}

\author{
Andrea Mancini ${ }^{1}$ (D) Ilaria Carafa ${ }^{1}$ Elena Franciosi ${ }^{1} \cdot$ Tiziana Nardin $^{2} \cdot$ Benedetta Bottari $^{3} \cdot$ Roberto $^{2}$ Larcher $^{2}$. \\ Kieran M. Tuohy ${ }^{1}$
}

Received: 28 February 2019 / Accepted: 3 November 2019/Published online: 6 December 2019

(C) The Author(s) 2019

\begin{abstract}
Purpose $\gamma$-Aminobutyric acid (GABA) is recognised as a potential metabolic bioactive food ingredient with increasing evidence of its effects on the gut-brain axis and systemic metabolic health. Different lactic acid bacteria are capable of producing GABA, particularly strains of Lactobacillus brevis. In this study, we characterized a Lb. brevis isolated from traditional alpine cheese ( $L b$. brevis DSM 32386) for its ability to accumulate high levels of GABA in the culture medium and for other important probiotic phenotypic traits.

Methods In vitro analysis were used to study the Lb. brevis DSM 32386 probiotic traits and the gene expression involved in GABA production

Result Lactobacillus brevis DSM 32386 converted monosodium glutamate to GABA more efficiently than the type strain $L b$. brevis DSM 20054, resulting in more than $200 \%$ of GABA produced. This ability seemed to be related to the higher transcriptional activation of the gene encoding for the glutamate (gad) decarboxylase antiporter $(\operatorname{gadC})$ and regulator ( $\mathrm{gadR}$ ). Lactobacillus brevis DSM 32386 performed well in vitro under the stress conditions mimicking the gastro-intestinal tract, being resistant to acid $\mathrm{pH}(\mathrm{pH} 2.5)$ and growing in simulated pancreatic fluid and $0.3 \%$ ox-bile.

Conclusion These preliminary studies indicate that Lb. brevis DSM 32386 holds promise as a starter for GABA-rich dairy fermented foods and possibly a promising next-generation probiotic microorganism in the context of the gut (microbiota):brain axis.
\end{abstract}

Keywords Probiotic $\cdot$ Lactobacillus brevis $\cdot$ Oxbile $\cdot \gamma$-Aminobutyric acid $\cdot$ GABA $\cdot$ GAD genes

\section{Introduction}

Formulation of the neurotransmitter $\gamma$-aminobutyric acid (GABA)-enriched foods or functional foods capable of

Electronic supplementary material The online version of this article (https://doi.org/10.1007/s13213-019-01527-x) contains supplementary material, which is available to authorized users.

Andrea Mancini

andrea.mancini@fmach.it

1 Department of Food Quality and Nutrition, Research and Innovation Centre, Fondazione Edmund Mach (FEM), Via E. Mach 1, 38010 San Michele all'Adige, Trento, Italy

2 Technology Transfer Centre, Fondazione Edmund Mach, (FEM), Via E. Mach 1, 38010 San Michele all'Adige, Trento, Italy

3 Department of Food and Drug Science, University of Parma, Viale delle Scienze 49/a, 43124 Parma, Italy delivery GABA is an opening research and development target for the food industry. These foods include dairy products, soybean, kimchi and juice products (Inoue et al. 2003; Hayakawa et al. 2004; Park and Oh 2007; Kim et al. 2009; Chang et al. 2009; Gangaraju et al. 2014). Moreover, the isolation of GABA-producing strains from diverse fermented food and from the human gut is providing considerable natural biotechnological solutions for efficacious functional food design (Komatsuzaki et al. 2005; Siragusa et al. 2007; Hiraga et al. 2008; Li et al. 2008). Those isolates could represent nextgeneration probiotics with specific mode of action based around their GABA-producing capability and possible modulation of the gut:brain axis (Bravo et al. 2011; Forsythe and Kunze 2013).

As defined by the Food and Agriculture Organization and the World Health Organization, probiotics are "live microorganisms which when administered in adequate amounts confer a health benefit on the host". Other 
definitions advanced through the years have been restrictive by specification of mechanisms, site of action, delivery format (e.g. food) or host (Hill et al. 2014). To accumulate in the intestinal tract, probiotics must first survive the various conditions specific to the digestive system, such as low $\mathrm{pH}$ in the stomach and the presence of bile acids in the intestines: these represent important selection criteria for putative probiotics (Kimoto-Nira et al. 2015). Probiotic efficacy has been shown to be species- and even strain-dependent since different bacterial strains can affect host via different modes of action (Maassen and Claassen 2008; Cani and Van Hul 2015). With a growing emphasis on demonstrating probiotic health effects, rational selection of probiotic strains based on their ability to modulate very specific physiological traits e.g. BSH activity, GABA or bacteriocin production, is becoming a prerequisite for probiotic selection.

Several GABA-producing LAB species isolated from traditional fermented food and beverages have been reported. These include $L b$. paracasei (Komatsuzaki et al. 2005, 2008; Siragusa et al. 2007), Lb. buchneri (Cho et al. 2007; Park and Oh 2007; Zhao et al. 2015), Lactococcus lactis (Nomura et al. 1998; Siragusa et al. 2007), Lb. delbrueckii subsp. bulgaricus (Siragusa et al. 2007), Lb. plantarum (Siragusa et al. 2007) and Lb. brevis (Ueno et al. 1997; Yokoyama et al. 2002; Park and Oh 2007; Siragusa et al. 2007; Li et al. 2008; Zhang et al. 2012). Cheese represents a rich source of LAB with potential GABA-producing properties (Nomura et al. 1998; Siragusa et al. 2007; Franciosi et al. 2015). The results of these findings offer potential alternatives to take advantage of GABA's health benefits through GABA-enriched cheeses. In a previous work, we isolated 276 strains from a specific raw cow milk "Nostrano-cheese", typical of the Trentino province (north, Alpine area) in Italy. Among those, $71 \%$ bacterial strains were able to produce GABA (Franciosi et al. 2015) and, in particular, the $L b$. brevis DSM 32386 possessed the highest GABA-producing rate (Franciosi et al. 2015; Carafa et al. 2019). In this work, we characterized the genetic basis of DSM 32386 strain's GABA production, as well as we assessed some characteristics considered important for probiotic selection, making it a good candidate as a starter of ingredient for functional GABA-enriched foods.

\section{Material and methods}

\section{Reagents}

All media constituents were purchased from Oxoid Ltd. (Basingstoke, UK) and Sigma Aldrich (Milan, Italy), chemicals were purchased from Sigma Aldrich.

\section{Bacterial strains, culture medium and growth conditions}

The stock culture collection of Lb. brevis DSM 32386 (Fondazione Edmund Mach collection and deposited at Leibniz-Institut DSMZ, Germany) and DSM 20054 (Leibniz-Institut DSMZ, Germany), as well as of $L b$. delbrueckii subs. lactis LL199 from the Department of Food and Drug Science - University of Parma collection (Belletti et al. 2009), were maintained at $-80^{\circ} \mathrm{C}$ in $20 \% \mathrm{v} / \mathrm{v}$ glycerol. Bacterial cells were propagated twice in MRS broth by incubation at $37^{\circ} \mathrm{C}$ for $16 \mathrm{~h}$ before each experiments.

\section{Y-Aminobutyric acid (GABA) production and quantification}

Glutamate decarboxylase (GAD) activity of Lb. brevis DSM 32386 and the production of GABA were measured as reported by Nomura et al. (Nomura et al. 1999). Briefly, Lb. brevis DSM 32386 and DSM 20054 were grown in MRS for $24 \mathrm{~h}$ at $37^{\circ} \mathrm{C}$ temperature. Cell cultures were then centrifuged ( 8600 rcf for $15 \mathrm{~min}$ at $4{ }^{\circ} \mathrm{C}$ ), washed twice with sterile PBS, and suspended in sterile $0.85 \% \mathrm{w} / \mathrm{v} \mathrm{NaCl}$ solution in order to achieve the A620 nm value of 2.5. One hundred microliters of cell suspension was then mixed with $900 \mu \mathrm{L}$ of $50 \mathrm{mM}$ sodium acetate buffer $(\mathrm{pH} 4.7)$ containing $7.0 \mathrm{mM}$ L-glutamate and $0.1 \mathrm{mM}$ pyridoxal phosphate. The reaction mixture was incubated for $24 \mathrm{~h}$ at $37{ }^{\circ} \mathrm{C}$ and filtered through a $0.22-\mu \mathrm{m}$ pore size filter (Minisart, Sartorius Stedim Biotech, Goettingen, Germany). The sample, diluted 10 times with sodium tetraborate $0.1 \mathrm{M}$ (pH adjusted to 10.5 ) and added to glycine, as internal standard to a final concentration of $10 \mathrm{mg} /$ $\mathrm{L}$, was stored at $-20^{\circ} \mathrm{C}$ before the analysis. L-Glutamic acid, glycine, and GABA were quantified as o-phthalaldehyde (OPA) adducts. The detection limit for GABA was estimated at $0.025 \mathrm{mg} / \mathrm{L}$ (three times the standard deviation of the GABA contents measured repeating ten times the analysis of a sample at unquantifiable content).

\section{GAD genes sequencing}

DNA was extracted with QIAamp DNA Blood Mini Kit (QIAGEN, Milan, Italy) from Lb. brevis DSM 32386 overnight broth culture following the manufacturer protocol. PCR amplification for the GABA genetic locus (gadR, gadA, gadC and gadB) was performed by using of specific primers (see Supplementary Table S1). PCR reactions were carried out in a 2720 Applied Biosystems Thermal Cycler (Applied Biosystems, Foster City, CA, USA). Amplified products were subsequently purified using the Promega PCR and Gel Clean Up system kit according to the manufacturer's instructions (Promega Corporation, Milan, Italy). Sequencing was carried out by Sequencing Platform Unit, Fondazione Edmund Mach 
(San Michele a/A, Trento, Italy). The identifications were refined by BLAST (1 www.ncbi.nlm.nih.gov/BLAST) and Clustal Omega (www.ebi.ac.uk/Tools/msa/clustalo/) alignment of the GAD DNA sequences to the reference genome.

\section{GAD genes expression}

Lactobacillus brevis DSM 32386 and DSM 20054 were inoculated in MRS in the presence or absence of $30 \mathrm{mg} / \mathrm{mL}$ of monosodium glutamate (MSG) for $12 \mathrm{~h}$. Total RNA was extracted from cultures at $0,3,7$ and $12 \mathrm{~h}$ using TriZol® (LifeTechnologies, Monza, Italy), according to the manufacturer's instructions, then samples were reverse transcribed using SensiFAST cDNA Synthesis Kit (BioLine AUROGENE s.r.1., Rome, Italy). The expression of target genes ( $\operatorname{gad} R, \operatorname{gadA}, \operatorname{gadB}$ and $\operatorname{gad} C$ ) was quantified by quantitative Real Time PCR (Supplementary Table S2). The assay was performed using $2 \times$ qPCRBIO SyGreen mix (PCRBIOSYSTEM, Resnova S.r.1., Rome, Italy) and carried out with a LightCycler 480 (Roche, LifeScience, Italy). The housekeeping gene tufl was used to normalize the expression of target genes. The comparative critical threshold method $\left(2^{-\Delta \Delta \mathrm{Ct}}\right)$ was used to calculate the relative gene expression with respect to time 0 . The RT-qPCR was performed in duplicates for each cDNA sample and independent experiments were carried out in triplicates.

\section{Tolerance to $\mathrm{pH}$, oxbile and pancreatic fluid}

Effect of low $\mathrm{pH}$ was studied by the method of Tsai et al. 2008. Briefly, one millilitre of culture containing about $10^{9}$ $\mathrm{CFU} / \mathrm{mL}$ of $\mathrm{LAB}$ was transferred into $9 \mathrm{ml}$ phosphatebuffered saline (PBS; $\mathrm{NaCl}, 137 \mathrm{mM} / \mathrm{L} ; \mathrm{KCl}, 2.7 \mathrm{mM} / \mathrm{L}$; $\left.\mathrm{Na}_{2} \mathrm{HPO}_{4}, 10 \mathrm{mM} / \mathrm{L} ; \mathrm{KH}_{2} \mathrm{PO}_{4}, 1.8 \mathrm{mM} / \mathrm{L}\right)$. The $\mathrm{pH}$ was adjusted to 2.0, 2.5 and 3.2 using $0.1 \mathrm{~N} \mathrm{HCl}$ and cells incubated at $37{ }^{\circ} \mathrm{C}$ for $3 \mathrm{~h}$. Control was performed at $\mathrm{pH}$ 7.2. After incubation, serial dilution plating on MRS agar was performed to determine viable bacterial counts. Plates were incubated anaerobically at $37^{\circ} \mathrm{C}$ for $48 \mathrm{~h}$ and acid tolerance was estimated by comparing the viable LAB bacteria counts in MRS agar for surviving cells. Data are presented as $\log (\mathrm{CFU} / \mathrm{mL}) \pm$ standard deviation. Five independent experiments were performed.

Tolerance for bile acids was performed on LAB cells exposed to low $\mathrm{pH}$. After the 3-h treatment described above, cells were centrifuged $(5000 \mathrm{~g}, 5 \mathrm{~min})$, washed with PBS $(\mathrm{pH} 7.2)$ and then grown in $9 \mathrm{~mL}$ MRS broth with and without $0.3 \%(\mathrm{w} / \mathrm{v})$ Oxgall bile for 3, 12 and $24 \mathrm{~h}$. Bile tolerance was estimated by comparing the viable LAB bacteria count in MRS with and without bile salt. Data are presented as $\log (\mathrm{CFU} / \mathrm{mL}) \pm$ standard deviation. Three independent experiments were performed.
Tolerance for pancreatic fluid was tested by inoculating actively growing bacteria $(10 \% \mathrm{v} / \mathrm{v}$ inoculum size) to the test medium $[150 \mathrm{mM} \mathrm{NaHCO}$ and $1.9 \mathrm{mg} / \mathrm{mL}$ pancreatin (Sigma, USA); $\mathrm{pH}$ 8.0]. The cultures were kept for $3 \mathrm{~h}$ in a shaking water bath (Certomat WR, B. Braun, Melsungen, Germany) at $37{ }^{\circ} \mathrm{C}$. Survival of LAB strains was examined by plating on MRS agar after 0 , and 3 h of incubation. Data are presented as $\log (\mathrm{CFU} / \mathrm{mL}) \pm$ standard deviation. Three independent experiments were performed.

\section{Antibiotic susceptibility test}

Lactobacillus brevis DSM 32386 and DSM 20054 phenotypic antibiotic resistance to ampicillin, vancomycin, gentamicin, erythromycin, clindamycin and tetracycline was assessed using the strip test M.I.C. Evaluator (Oxoid Ltd., Basingstoke, UK) following the manufacturer's instruction. The strips consist of a gradient of stabilised antimicrobial covering 15 doubling dilutions. M.I.C.E. strips were used on a pre-inoculated agar plate, with formation of defined concentration gradient in the area around it. Minimum Inhibitory Concentration (MIC) was determined at the border of growth inhibition around the strip. Values were compared to the guidelines for facultative heterofermentative lactobacilli as indicated in the "Guidance on the assessment of bacterial susceptibility to antimicrobials of human and veterinary importance" by the European Food Safety Authority (EFSA) (EFSA Panel on Additives and Products or Substances used in Animal Feed (FEEDAP) 2012).

\section{Detection of antibiotic resistance genes}

Genomic DNA from overnight cultures of Lb. brevis DSM 32386, Lb. brevis DSM 20054 and Lb. delbrueckii subs. lactis LL199 was extracted with QIAamp DNA Blood Mini Kit (QIAGEN, Milan, Italy). Polymerase chain reactions was used to determine antibiotic resistance genes by genespecific primers (Table 4), by using genomic DNA from $L b$. delbrueckii subs. lactis resistant strain LL199 as positive control. After an initial denaturation step of $94{ }^{\circ} \mathrm{C}$ for $5 \mathrm{~min}$, the amplification programme consisted of 35 cycles of: $94^{\circ} \mathrm{C}$ for $1 \mathrm{~min}$, annealing temperature (Table 4 ) for $1 \mathrm{~min}, 72^{\circ} \mathrm{C}$ for 2 min. PCR reactions were carried out in a 2720 Applied Biosystems Thermal Cycler (Applied Biosystems, Foster City, CA, USA) and amplicons were analysed on $1 \%$ agarose gel to confirm presence and fragment size.

\section{Statistics}

Paired $t$ test was used to compare differences between the effect of a particular stress condition and the control, or between different gene expression levels. The level of significance was set at $p<0.05$. 


\section{Results}

\section{Lb. brevis DSM 32386 GABA production}

Our previous study identified several cheese isolates capable of producing GABA (Franciosi et al. 2015). Starting from this preliminary information, we focused on $L b$. brevis DSM 32386. Firstly, the GABA production rate of $L b$. brevis DSM 32386 was compared to that of the type strain $L b$. brevis DSM 20054. After incubation at $37^{\circ} \mathrm{C}$ for $24 \mathrm{~h}$, DSM 32386 was able to produce considerable higher quantity of GABA $(262.06 \pm 15.42 \mathrm{mg} / \mathrm{L})$ compared to the type strain $(78.27 \pm$ $18.61 \mathrm{mg} / \mathrm{L})(p<0.00001)$.

Two different GAD encoding genes have been characterized in different $L b$. brevis stains, namely gadA and gadB (Nomura et al. 1998; Siragusa et al. 2007; Komatsuzaki et al. 2008; Hiraga et al. 2008). gadA is located adjacent to and downstream of the glutamate/GABA antiporter gene ( $\mathrm{gadC}$ ), commonly referred as gadCA. They form an operon with the operon regulator $g a d R$, being immediately upstream of gadCA. gadB is located separately from the other gad genes (Li et al. 2013) (Fig. 1A). By the use of fourteen sets of primers based on the nucleotidic sequence of the reference strain ATCC367 (Supplementary Table S1), the DSM 32386 operon and $g a d B$ sequences were amplified confirming the presence of each genetic locus involved in the GABA production within DSM 32386 strain. The gene sequences shared high similarity with the ATCC367 strain, revealing the absence of any polymorphisms in the operon system or in the antiporter. We thus asked whether this high ability was related to an increase in gene expression of such genes in the presence of glutamate. The RT-qPCR analysis of gad genes showed a different expression profile in Lb. brevis DSM 32386 and DSM 20054 genes, both in the presence or absence of the operon inducer glutamate (Fig. 1B). With the exception of gadA after $7 \mathrm{~h}$ and gadC after $12 \mathrm{~h}$, gad genes are repressed in the absence of glutamate, while the presence of glutamate induced their expression in both strains. All gad genes were up-regulated to a greater degree by DSM 32386 than in the type strain $(\mathrm{gadA}, p<0.001 ; \operatorname{gadB}, p<0.001 ; \operatorname{gadC}, p<0.01$; $\operatorname{gadR}, p<0.01$ ), especially after $7 \mathrm{~h}$ of growth (Fig. 1B).

\section{Lb. brevis DSM 32386 tolerance to simulated gastrointestinal conditions}

One of the characteristics required for being a probiotic is the ability to survive the gastrointestinal (GI) physiochemical environment. Therefore the Lb. brevis DSM 32386 tolerance to acid $\mathrm{pH}$, bile and pancreatic fluid, mimicking the acidic and liptolytic environment present along the GI tract was measured. Lb. brevis DSM 32386 was more resistant to acid $\mathrm{pH}$ than the type strain DSM 20054, being able to survive to $3 \mathrm{~h}$ exposure at $\mathrm{pH} 2.5$ and 3.2, but not to $\mathrm{pH} 2.0$ (Table 1).
Moreover, incubation of DSM 32386 strain in growth medium containing pancreatic fluid had no effect on its viability and fitness (Table 1). The type strain DSM 20054 behaved in a similar manner and not statistically significant differences were observed between the survivals of both strains in pancreatic fluid (Table 1).

Subsequently DSM 32386 cells that survived pH 2.5 (3 h) acid treatment were cultured in MRS broth in the presence or absence of $0.3 \%$ Oxbile. Lb. brevis DSM 32386 cells were able to resist to bile salts, even with a significant cell reduction over time (Table 2). DSM 32386 cells surviving the $\mathrm{pH} 2.5$ acid treatment grew at rate comparable to the not $\mathrm{pH}$-treated cells when transferred into MRS broth (Table 2).

\section{Antibiotic susceptibility testing}

Regarding the safety assurance of probiotic organisms in food, FAO/WHO guidelines (2002) suggest testing probiotic strains for antibiotic resistance. Primary testing of the antibiotic resistance patterns of Lb. brevis DSM 32386 and DSM 20054 strains was carried out by the E-strip method, following manufacturer's instruction. According to the sensitivity guidelines provided by EFSA (EFSA Panel on Additives and Products or Substances used in Animal Feed (FEEDAP) 2012), DSM 32386 was interpreted to be sensitive to vancomycin, clindamycin, tetracycline, ampicillin and erythromycin, while resistant to gentamycin with MIC being two times more the indicated cut off value (Table 3). Instead, DSM 20054 was interpreted to be sensitive to vancomycin, tetracycline, ampicillin and erythromycin and resistant to gentamycin and clindamycin with MICs being four and sixteen times more the indicated cut-off values (Table 3 ).

We therefore analysed the presence of the antibiotic resistance cassettes at the genomic level by PCR (Table 4) using Lb. delbrueckii subs. lactis LL199 as positive control, as already reported resistant to clindamycin, tetracycline, erythromycin and gentamycin (Belletti et al. 2009). Only the erythromycin resistance gene $\operatorname{erm}(A)$ and tetracycline cassette tet $(W)$ were detected in both $L b$. brevis strains, while clindamycin, ampicillin and gentamycin resistance genes were not detectable.

\section{Discussion and conclusion}

The identification of strains with specific mode of action or biochemical traits capable of mediating specific host physiological responses represents the basis of a rational scientific selection of the next generation probiotic strains designed to mediate specific health effects in the host.

High $\gamma$-aminobutyric acid (GABA)-producing LAB strains isolated from fermented food, including cheese (Siragusa et al. 2007; Franciosi et al. 2015) and fresh 
Fig. 1 GAD system in Lb. brevis and genes expression in response to $30 \mathrm{mg} / \mathrm{ml}$ of monosodium glutamate. (A) The gad operon genes and gadB gene in Lb. brevis; (B) RT-qPCR has been used to assess the transcription level of the gad in DSM 32386 and DSM 20054 as described in 'Material and methods' section. Comparative critical threshold method $\left(2^{-} \Delta \Delta^{\mathrm{Ct}}\right)$ was used to calculate the relative gene expression with respect to time 0. Data are presented as mean $\pm \mathrm{sd}, N=3$. $* p<$ $0.05, * * p<0.01$, paired $t$ test, DSM 32386 relative expression vs DSM 20054 relative expression a

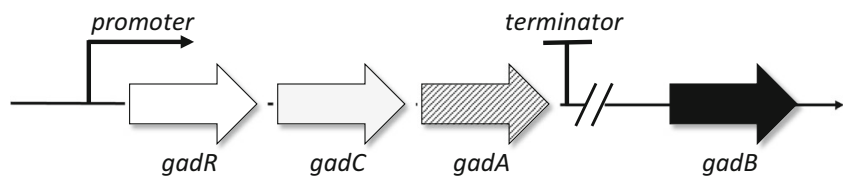

b
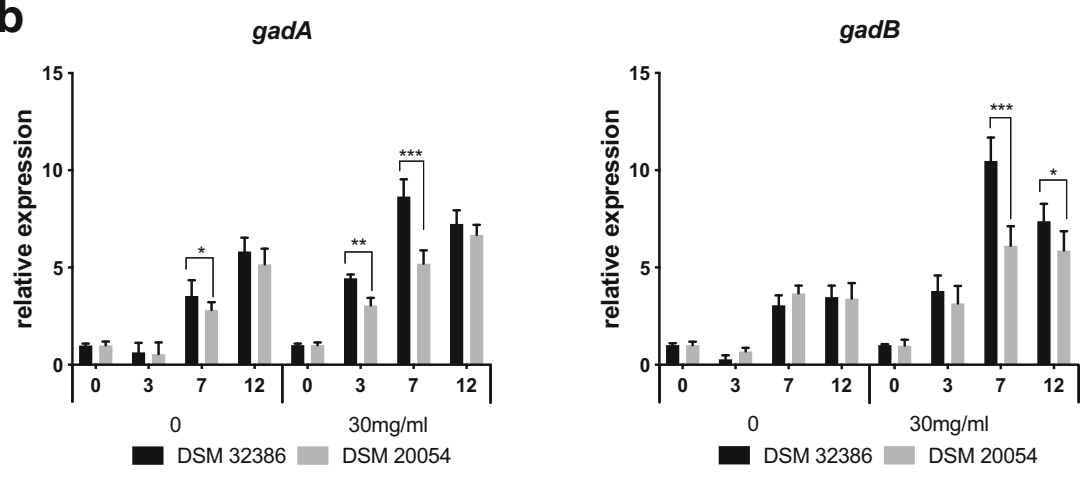

gadC

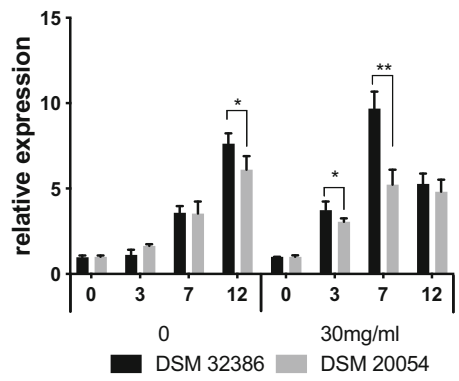

gadR

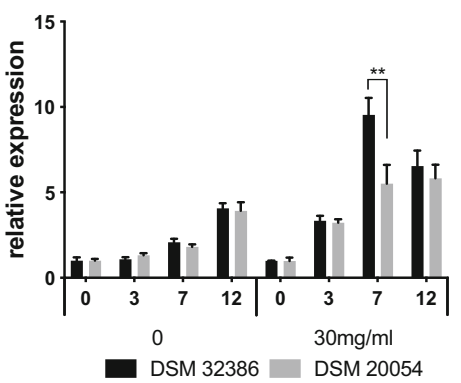

unpasteurized milk (Fan et al. 2011) or by strains isolated from the human intestinal tract represent a rich and natural bioresource for identification of putative probiotic (Monte et al. 2009; Settanni and Moschetti 2010; Montel et al. 2014). GABA is produced primarily from the irreversible $\alpha$ decarboxylation of L-glutamate by the enzyme glutamate decarboxylase (GAD) (Cotter and Hill 2003). In the intracellular glutamate decarboxylase (GAD) system, glutamate is imported into cells by the GABA antiporter, decarboxylated by intracellular GAD to produce GABA and subsequently GABA is exported from the cells via the antiporter (Sanders et al. 1998; Small and Waterman 1998; Li et al. 2013). Two GAD-encoding genes, named gadA and $\operatorname{gadB}$ are present in Lb. brevis (Li et al. 2013; Wu and Shah 2016; Yunes et al.
2016; Wu et al. 2017; Wu and Shah 2018). The high GABA production by Lb. brevis DSM 32386 appears not to be due to mutation in these genes as we identified the presence of the intact gad operon at the genomic level. In general, the bacterial GAD system includes (i) a glutamate uptake by a specific transporter followed by (ii) the removal of an intracellular proton during glutamate decarboxylation and (iii) GABA export from the cell via an antiporter. This leads to an increase in the cytoplasmic $\mathrm{pH}$ (by the removal of hydrogen ions) and also slightly increasing the extracellular $\mathrm{pH}$ (by the exchange of extracellular glutamate for GABA) (Cotter and Hill 2003; $\mathrm{Wu}$ et al. 2017). Interestingly, compared to the type strain DSM 20054, Lb. brevis DSM 32386 induces a higher expression of both gadA and gadB genes over time, accompanied by

Table 1 Analysis of acid and pancreatic fluid tolerance Lb. brevis DSM 32386 and Lb. brevis DSM 20054

\begin{tabular}{|c|c|c|c|c|c|c|c|}
\hline \multirow[t]{2}{*}{ Strain } & \multicolumn{5}{|c|}{ Acid tolerance ( $\mathrm{pH} 2.0,2.5$ and 3.2) } & \multicolumn{2}{|c|}{ Resistance to pancreatic fluid } \\
\hline & $0 \mathrm{~h}$ & $\mathrm{pH} 7.2,3 \mathrm{~h}$ & $\mathrm{pH} 3.2,3 \mathrm{~h}$ & $\mathrm{pH} 2.5,3 \mathrm{~h}$ & $\mathrm{pH} \mathrm{2,3} \mathrm{h}$ & $0 \mathrm{~h}$ & $3 \mathrm{~h}$ \\
\hline DSM 32386 & $9.64 \pm 0.40^{\mathrm{a}}$ & $9.09 \pm 0.21$ & $8.85 \pm 0.64$ & $7.75 \pm 0.74$ & nd & $7.84 \pm 0.56^{\mathrm{a}}$ & $7.92 \pm 0.45$ \\
\hline DSM 20054 & $9.87 \pm 0.70$ & $8.61 \pm 0.22$ & $8.43 \pm 0.37$ & n.d & n.d & $8.11 \pm 1.13$ & $7.90 \pm 0.51$ \\
\hline
\end{tabular}

${ }^{\mathrm{a}}$ Bacterial counts are converted to $\log \mathrm{CFU} / \mathrm{ml}$ 
Table 2 Effect of bile salts on $L b$ brevis DSM 32386 after low $\mathrm{pH}$ treatment

\begin{tabular}{lllll}
\hline Time $(\mathrm{h})$ & 0 & 3 & 12 & 24 \\
\hline MRS & $5.38 \pm 0.79^{\mathrm{b}}$ & $4.16 \pm 0.45$ & $6.29 \pm 0.51$ & $8.55 \pm 0.37$ \\
${\text { MRS }+ \text { oxbile }{ }^{\mathrm{a}}}^{5.78 \pm 1.13}$ & $2.03 \pm 1.3^{*}$ & $2.3 \pm 1.41^{* *}$ & $3.12 \pm 1.55^{* * *}$ \\
\hline${ }^{\mathrm{a}}$ MRS + oxbile means MRS broth with $0.3 \%$ Oxgall & & \\
${ }^{\mathrm{b}}$ Bacteria counts are converted to log CFU/ml & & \\
$* p<0.05$ & & & \\
$* * p<0.01$ & &
\end{tabular}

an increased level of gadC, the gene encoding for the antiporter and gadR, encoding for the positive operon regulator. Indeed, the higher activation of the GAD system observed could account for the high GABA production.

The physiological activity of GABA makes it an interesting bioactive molecule which has already been used as a food supplement in pure form (Andrighetto et al. 2002). In recent years, researchers have reported a number of placebo controlled studies in which GABA was administered as a food or oral supplement to healthy participants (Am et al. 2005; Nakamura et al. 2009; Kanehira et al. 2011; Yoto et al. 2012; Li et al. 2015; Steenbergen et al. 2015). A pioneering study in patients with mild hypertension reported that daily intake of fermented milk containing $10-12 \mathrm{mg} / 100 \mathrm{~mL}$ of GABA could significantly lower blood pressure within 2 weeks (Inoue et al. 2003). In these terms, fermented milk enriched in GABA produced by Lb. brevis DSM 32386 may have commercial potential as a health-oriented dairy product as well as any direct probiotic effect of the high GABA-producing strain.

To be considered a possible probiotic, the bacterial strain, in addition to being a GRAS organism, should be able to survive within the human GI tract and therein mediate a specific health-related activity in the right environment (Lee and Salminen 1995; Salminen et al. 1998). Testing for tolerance of low $\mathrm{pH}$, bile acids and pancreatic fluids have often been considered as good indicators for survival through the GI tract. In this study, Lb. brevis DSM 32386 strain performed well in the in vitro tests, and survival through the stomach is likely. In addition, previous studies have shown that food matrix plays an important role in probiotic survival of gastric $\mathrm{pH}$ (Charalampopoulos et al. 2003; Stadler and Viernstein 2003; Mancini Andrea 2017) and cheeses in particular appears to effectively protect probiotics from low $\mathrm{pH}$ encountered in the stomach (Boylston et al. 2004). However, survival under in vivo conditions in human subjects should be tested.

Lactic acid bacteria are intrinsically resistant to many antibiotics (Delgado et al. 2005; Fukao et al. 2009; Devirgiliis et al. 2013; Guo et al. 2017; Campedelli et al. 2019). In many cases, resistances are not, however, transmissible, and the species are also sensitive to many clinically used antibiotics even in the case of a lactic acid bacteria-associated opportunistic infection. Among 187 isolates, from 55 European probiotic products showed that $79 \%$ of the isolates were resistant to kanamycin and $65 \%$ of the isolates were vancomycin resistant. Remaining resistances were in the order of tetracycline (26\%), penicillin G (23\%), erythromycin (16\%) and chloramphenicol (11\%). Overall, $68.4 \%$ of the isolates showed resistance against multiple antibiotics including intrinsic resistance (Temmerman et al. 2003). The antimicrobial susceptibility tests indicated that $L b$. brevis DSM 32386 was resistant to gentamycin, and the type strain DSM 20054 as resistant to gentamycin and clindamycin. In general, Lactobacillus species are intrinsically resistant to aminoglycosides such as gentamicin, with resistance reported in strains isolated from different sources, as in the case of Lb. brevis isolated from fermented vegetables (Abriouel et al. 2015). EFSA requires the assessment of antibiotic resistance in strain introduced in the food chain, with particular attention in distinguishing between bacterial species with "intrinsic resistance" or "acquired resistance". Since intrinsic resistance is specific for a bacterial species or genus, when all strains within a given taxonomic group show phenotypic resistance to an antimicrobial, this resistance can be considered intrinsic to the taxonomic group (EFSA Panel on Additives and Products or Substances used in Animal Feed (FEEDAP) 2012). In our study, gentamicin resistance was detected in both Lb. brevis DSM 32386 and
Table 3 Resisance of $L b$. brevis DSM 32386 and $L b$. brevis DSM 20054 to various antimicrobial agents

\begin{tabular}{lllllll}
\hline & CA & VA & DA & TE & AM & ER \\
\hline Cut-off value $(\mu \mathrm{g} / \mathrm{ml})^{\mathrm{a}}$ & 16 & 2 & 1 & 8 & 4 & 1 \\
DSM 32386 MIC $(\mu \mathrm{g} / \mathrm{ml})$ & 32 & - & 0.03 & 4 & 2 & 0.25 \\
DSM 20054 MIC $(\mu \mathrm{g} / \mathrm{ml})$ & 64 & - & 16 & 4 & 2 & 0.5 \\
\hline
\end{tabular}

${ }^{a}$ Microbiological cut-off values as indicated by EFSA; CA, Gentamycin; VA, Vancomycin; DA, Clindamycin; TE, Tetracycline; AM, Ampicillin; ER, Erythromycin 
Table 4 Gene specific primers and condition for PCR reactions

\begin{tabular}{|c|c|c|c|c|c|}
\hline Antibiotic & $\begin{array}{l}\text { Antibiotic resistance } \\
\text { cassette }\end{array}$ & Primers $5^{\prime}-3^{\prime}$ & $\begin{array}{l}\text { Annealing } \\
\text { temperatures }\left({ }^{\circ} \mathrm{C}\right)\end{array}$ & $\begin{array}{l}\text { Size } \\
(\mathrm{bp})\end{array}$ & References \\
\hline \multirow[t]{6}{*}{ Ampicillin } & \multirow[t]{2}{*}{ mecA } & CGTSTTTAACTAAGTATSGY & \multirow[t]{2}{*}{58} & \multirow[t]{2}{*}{1429} & \multirow[t]{2}{*}{ Guo et al. (2017) } \\
\hline & & GGGATCATAGCGTCATTATTC & & & \\
\hline & \multirow[t]{2}{*}{ bla } & TAGGTTCAGATTGGCCCTTAG & \multirow[t]{2}{*}{51} & \multirow[t]{2}{*}{297} & \multirow[t]{2}{*}{ Guo et al. (2017) } \\
\hline & & CATARTTCCGATAATASMGCC & & & \\
\hline & \multirow[t]{2}{*}{ claZ } & GCATGRTAACCATCACAWAC & \multirow[t]{2}{*}{58} & \multirow[t]{2}{*}{240} & \multirow[t]{2}{*}{ Guo et al. (2017) } \\
\hline & & ACTTCAACACCTGCTGCTTTC & & & \\
\hline \multirow[t]{2}{*}{ Erythromycin } & $\operatorname{erm}(A)$ & $\begin{array}{l}\text { AAGCGGTAAACCCCTCTGA } \\
\text { TTCGCAAATCCCTTCTCAAC }\end{array}$ & 55 & 190 & Nawaz et al. (2011) \\
\hline & $\operatorname{erm}(B)$ & $\begin{array}{l}\text { GAAAAGRTACTCAACCAAATA } \\
\text { AGTAACGGTACTTAAATTGTTTAC }\end{array}$ & 52 & 642 & Nawaz et al. (2011) \\
\hline Gentamycin & $a a c$ & $\begin{array}{l}\text { CCAAGAGCAATAAGGGCATA } \\
\text { CACTATCATAACCACTACCG }\end{array}$ & 60 & 220 & Nawaz et al. (2011) \\
\hline \multirow[t]{3}{*}{ Clindamycin } & \multirow[t]{2}{*}{$\operatorname{lun}(A)$} & GCTAATATTGTTTAAATCGTCAAT & \multirow[t]{2}{*}{55} & \multirow[t]{2}{*}{323} & \multirow[t]{2}{*}{ Guo et al. (2017) } \\
\hline & & GGTGGCTGGGGGGTAGATGTATTAACTGG & & & \\
\hline & $\operatorname{lun}(B)$ & $\begin{array}{l}\text { GCTTCTTTTGAAATACATGGTATTTTTCGATC } \\
\text { CCTACCTATTGTTTGTGGAA }\end{array}$ & 54 & 925 & Guo et al. (2017) \\
\hline Tetracycline & tetM1 & GCTTGATCCCCAGTAAGTCA & 55 & 401 & Guo et al. (2017) \\
\hline & & GGTGAACATCATAGACACGC & & & \\
\hline & tetL1 & $\begin{array}{l}\text { GTMGTTGCGCGCTATATTCC } \\
\text { GTGAAMGRWAGCCCACCTAA }\end{array}$ & 55 & 696 & Fukao et al. (2009) \\
\hline & $\operatorname{tet}(W)$ & $\begin{array}{l}\text { GAGAGCCTGCTATATGCCAGC GGGCGTAT } \\
\text { CCACAATGTTAAC }\end{array}$ & 64 & 168 & Fukao et al. (2009) \\
\hline & $\operatorname{tet}(S)$ & ATCAAGATATTAAGGAC & 56 & 573 & Nawaz et al. (2011) \\
\hline & & TTCTCTATGTGGTAATC & & & \\
\hline & $\operatorname{tet}(L)$ & $\begin{array}{l}\text { CATTTGGTCTTATTGGATCG } \\
\text { ATTACACTTCCGATTTCGG }\end{array}$ & 50 & 456 & Nawaz et al. (2011) \\
\hline & $\operatorname{tet}(K)$ & $\begin{array}{l}\text { TTAGGTGAAGGGTTAGGTCC } \\
\text { GCAAACTCATTCCAGAAGCA }\end{array}$ & 55 & 697 & Nawaz et al. (2011) \\
\hline & $\operatorname{tet}(O)$ & $\begin{array}{l}\text { AACTTAGGCATTCTGGCTCAC } \\
\text { TCCCACTGTTCCATATCGTCA }\end{array}$ & 52 & 515 & Nawaz et al. (2011) \\
\hline & $\operatorname{tet}(Q)$ & $\begin{array}{l}\text { AGAATCTGCTGTTTGCCAGTG } \\
\text { CGGAGTGTCAATGATATTGCA }\end{array}$ & 56 & 169 & Nawaz et al. (2011) \\
\hline & $\operatorname{tet}(M)$ & $\begin{array}{l}\text { GTTAAATAGTGTTCTTGGAG } \\
\text { CTAAGATATGGCTCTAACAA }\end{array}$ & 55 & 576 & Nawaz et al. (2011) \\
\hline
\end{tabular}

20054 strains, being more evident in the type strains, thus allowing us to consider it as natural and not acquired antibiotic resistance, therefore no particular safety concern is associated with this intrinsic type of resistance.

From a molecular point of view, any gentamicin amplicons was evidenced by PCR, while $L b$. brevis strains harboured the $\operatorname{erm}(A)$ and $\operatorname{tet}(W)$ cassette, respectively, for erythromycin and tetracycline resistance, that were phenotypically confirmed but they were below the EFSA cut-off values. In Lactobacillus ssp., the most common erm cassette is $\operatorname{erm}(B)$ also detected in $L b$. brevis, while $\operatorname{erm}(A)$ is rarely found (Nawaz et al. 2011). Genes that confer tetracycline resistance in lactobacilli can be tet $(S),(W),(K),(L)$ and $(O)$, widely distributed between species and mainly represented in $L b$. brevis by tet $(M)$ and tet $(S)$ (Fukao et al. 2009; Nawaz et al. 2011; Devirgiliis et al. 2013; Campedelli et al. 2019). A more comprehensive overview and information on the genetic basis of Lb. brevis DSM 32386 antibiotic resistance will be derived by genome sequencing that represent the further step in the study of this strain.
Even though in vivo investigations are needed, altogether these preliminary results showed that the $L b$. brevis GABA producing DSM 32386 strain represents a promising starter for manufacturing GABA-rich cultured dairy foods to be used as functional food as well as a promising next generation probiotic in the context of the gut(microbiota):brain axis. Tests on GABA level availability in DSM 32386 dairy products are ongoing. Overall, our data indicate the importance of studying and preserving the traditional raw milk cheese microbiome. Traditional cheeses represent an important source of microbial biodiversity where new LAB strains with potential health-promoting properties can be isolated.

Acknowledgements The authors would like to thank Dr. Massimo Pindo from the Genomics Platform at Fondazione Edmund Mach.

Funding The research received grant support from Trento Province (Accordo di Programma, ADP). 


\section{Compliance with ethical standards}

Conflict of interest The authors declare that they have no conflict of interest.

Research involving human participants and/or animals N/A

Informed consent N/A

Open Access This article is licensed under a Creative Commons Attribution 4.0 International License, which permits use, sharing, adaptation, distribution and reproduction in any medium or format, as long as you give appropriate credit to the original author(s) and the source, provide a link to the Creative Commons licence, and indicate if changes were made. The images or other third party material in this article are included in the article's Creative Commons licence, unless indicated otherwise in a credit line to the material. If material is not included in the article's Creative Commons licence and your intended use is not permitted by statutory regulation or exceeds the permitted use, you will need to obtain permission directly from the copyright holder. To view a copy of this licence, visit http://creativecommons.org/licenses/by/4.0/.

\section{References}

Abriouel H, M del C CM, Lavilla Lerma L et al (2015) New insights in antibiotic resistance of Lactobacillus species from fermented foods. Food Res Int 78:465-481. https://doi.org/10.1016/j.foodres.2015.09.016

Am A, S H, K H et al (2005) Relaxation and immunity enhancement effects of gamma-aminobutyric acid (GABA) administration in humans. BioFactors Oxf Engl 26:201-208. https://doi.org/10. 1002/biof.5520260305

Mancini Andrea (2017) Modulazione del microbiota in soggetti sani o in presenza di processi patologici: focus sull'asse intestino:fegato: cervello. PhD Thesis 'http://dspace-unipr.cineca.it/bitstream/1889/ 3353/1/ManciniA-PhD\%20thesis_rev.pdf, University of Parma

Andrighetto C, Borney F, Barmaz A et al (2002) Genetic diversity of Streptococcus thermophilus strains isolated from Italian traditional cheeses. Int Dairy J 12:141-144. https://doi.org/10.1016/S09586946(01)00134-0

Belletti N, Gatti M, Bottari B et al (2009) Antibiotic resistance of lactobacilli isolated from two Italian hard cheeses. J Food Prot 72: 2162-2169

Boylston TD, Vinderola CG, Ghoddusi HB, Reinheimer JA (2004) Incorporation of bifidobacteria into cheeses: challenges and rewards. Int Dairy J 14:375-387. https://doi.org/10.1016/j.idairyj.2003.08.008

Bravo JA, Forsythe P, Chew MV et al (2011) Ingestion of Lactobacillus strain regulates emotional behavior and central GABA receptor expression in a mouse via the vagus nerve. Proc Natl Acad Sci U S A 108:16050-16055. https://doi.org/10.1073/pnas.1102999108

Campedelli I, Mathur H, Salvetti E et al (2019) Genus-wide assessment of antibiotic resistance in Lactobacillus spp. Appl Environ Microbiol 85. https://doi.org/10.1128/AEM.01738-18

Cani PD, Van Hul M (2015) Novel opportunities for next-generation probiotics targeting metabolic syndrome. Curr Opin Biotechnol 32:21-27. https://doi.org/10.1016/j.copbio.2014.10.006

Carafa I, Stocco G, Nardin T et al (2019) Production of naturally $\gamma$ aminobutyric acid-enriched cheese using the dairy strains Streptococcus thermophilus $84 \mathrm{C}$ and Lactobacillus brevis DSM 32386. Front Microbiol 10. https://doi.org/10.3389/fmicb.2019.00093
Chang C-T, Hsu C-K, Chou S-T et al (2009) Effect of fermentation time on the antioxidant activities of tempeh prepared from fermented soybean using Rhizopus oligosporus. Int J Food Sci Technol 44: 799-806. https://doi.org/10.1111/j.1365-2621.2009.01907.x

Charalampopoulos D, Pandiella SS, Webb C (2003) Evaluation of the effect of malt, wheat and barley extracts on the viability of potentially probiotic lactic acid bacteria under acidic conditions. Int $\mathrm{J}$ Food Microbiol 82:133-141

Cho YR, Chang JY, Chang HC (2007) Production of gammaaminobutyric acid (GABA) by Lactobacillus buchneri isolated from kimchi and its neuroprotective effect on neuronal cells. J Microbiol Biotechnol 17:104-109

Cotter PD, Hill C (2003) Surviving the acid test: responses of grampositive bacteria to low $\mathrm{pH}$. Microbiol Mol Biol Rev 67:429-453. https://doi.org/10.1128/MMBR.67.3.429-453.2003

Delgado S, Flórez AB, Mayo B (2005) Antibiotic susceptibility of Lactobacillus and Bifidobacterium species from the human gastrointestinal tract. Curr Microbiol 50:202-207. https://doi.org/10.1007/ s00284-004-4431-3

Devirgiliis C, Zinno P, Perozzi G (2013) Update on antibiotic resistance in foodborne Lactobacillus and Lactococcus species. Front Microbiol 4. https://doi.org/10.3389/fmicb.2013.00301

EFSA Panel on Additives and Products or Substances used in Animal Feed (FEEDAP) (2012) Guidance on the assessment of bacterial susceptibility to antimicrobials of human and veterinary importance: guidance on the assessment of bacterial antimicrobial susceptibility. EFSA J 10:2740. https://doi.org/10.2903/j.efsa.2012.2740

Fan E, Huang J, Hu S et al (2011) Cloning, sequencing and expression of a glutamate decarboxylase gene from the GABA-producing strain Lactobacillus brevis CGMCC 1306. Ann Microbiol 62:689-698. https://doi.org/10.1007/s13213-011-0307-5

Forsythe P, Kunze WA (2013) Voices from within: gut microbes and the CNS. Cell Mol Life Sci CMLS 70:55-69. https://doi.org/10.1007/ s00018-012-1028-z

Franciosi E, Carafa I, Nardin T et al (2015) Biodiversity and $\gamma$ aminobutyric acid production by lactic acid bacteria isolated from traditional alpine raw cow's milk cheeses. BioMed Res Int 2015:111. https://doi.org/10.1155/2015/625740

Fukao M, Tomita H, Yakabe T et al (2009) Assessment of antibiotic resistance in probiotic strain Lactobacillus brevis KB290. J Food Prot 72:1923-1929. https://doi.org/10.4315/0362-028X-72.9.1923

Gangaraju D, Murty VR, Prapulla SG (2014) Probiotic-mediated biotransformation of monosodium glutamate to $\gamma$-aminobutyric acid: differential production in complex and minimal media and kinetic modelling. Ann Microbiol 64:229-237. https://doi.org/10.1007/s13213-013-0655-4

Guo H, Pan L, Li L et al (2017) Characterization of antibiotic resistance genes from Lactobacillus isolated from traditional dairy products: antibiotic resistance of Lactobacillus. J Food Sci 82:724-730. https://doi.org/10.1111/1750-3841.13645

Hayakawa K, Kimura M, Kasaha K et al (2004) Effect of a gammaaminobutyric acid-enriched dairy product on the blood pressure of spontaneously hypertensive and normotensive Wistar-Kyoto rats. $\mathrm{Br}$ J Nutr 92:411-417

Hill C, Guarner F, Reid G et al (2014) Expert consensus document. The International Scientific Association for Probiotics and Prebiotics consensus statement on the scope and appropriate use of the term probiotic. Nat Rev Gastroenterol Hepatol 11:506-514. https://doi. org/10.1038/nrgastro.2014.66

Hiraga K, Ueno Y, Oda K (2008) Glutamate decarboxylase from Lactobacillus brevis: activation by ammonium sulfate. Biosci Biotechnol Biochem 72: 1299-1306. https://doi.org/10.1271/bbb.70782

Inoue K, Shirai T, Ochiai H et al (2003) Blood-pressure-lowering effect of a novel fermented milk containing gamma-aminobutyric acid (GABA) in mild hypertensives. Eur J Clin Nutr 57:490-495. https://doi.org/10.1038/sj.ejcn.1601555 
Kanehira T, Nakamura Y, Nakamura K et al (2011) Relieving occupational fatigue by consumption of a beverage containing $\gamma$-amino butyric acid. J Nutr Sci Vitaminol (Tokyo) 57:9-15

Kim JY, Lee MY, Ji GE et al (2009) Production of gamma-aminobutyric acid in black raspberry juice during fermentation by Lactobacillus brevis GABA100. Int J Food Microbiol 130:12-16. https://doi.org/ 10.1016/j.ijfoodmicro.2008.12.028

Kimoto-Nira H, Suzuki S, Suganuma H et al (2015) Growth characteristics of Lactobacillus brevis KB290 in the presence of bile. Anaerobe 35:96-101. https://doi.org/10.1016/j.anaerobe.2015.08.001

Komatsuzaki N, Nakamura T, Kimura T, Shima J (2008) Characterization of glutamate decarboxylase from a high gamma-aminobutyric acid (GABA)-producer, Lactobacillus paracasei. Biosci Biotechnol Biochem 72:278-285. https://doi.org/10.1271/bbb.70163

Komatsuzaki N, Shima J, Kawamoto S et al (2005) Production of $\gamma$ aminobutyric acid (GABA) by Lactobacillus paracasei isolated from traditional fermented foods. Food Microbiol 22:497-504. https:// doi.org/10.1016/j.fm.2005.01.002

Lee Y-K, Salminen S (1995) The coming of age of probiotics. Trends Food Sci Technol 6:241-245. https://doi.org/10.1016/S09242244(00)89085-8

Li H, Gao D, Cao Y, Xu H (2008) A high $\gamma$-aminobutyric acidproducingLactobacillus brevis isolated from Chinese traditionalpaocai. Ann Microbiol 58:649-653. https://doi.org/10. 1007/BF03175570

Li H, Li W, Liu X, Cao Y (2013) gadA gene locus in Lactobacillus brevis NCL912 and its expression during fed-batch fermentation. FEMS Microbiol Lett 349:108-116. https://doi.org/10.1111/1574-6968.12301

Li J, Zhang Z, Liu X et al (2015) Study of GABA in healthy volunteers: pharmacokinetics and pharmacodynamics. Drug Metab Transp 260. https://doi.org/10.3389/fphar.2015.00260

Maassen CBM, Claassen E (2008) Strain-dependent effects of probiotic lactobacilli on EAE autoimmunity. Vaccine 26:2056-2057. https:// doi.org/10.1016/j.vaccine.2008.02.035

Monte MJ, Marin JJG, Antelo A, Vazquez-Tato J (2009) Bile acids: chemistry, physiology, and pathophysiology. World J Gastroenterol 15:804-816

Montel M-C, Buchin S, Mallet A et al (2014) Traditional cheeses: rich and diverse microbiota with associated benefits. Int $\mathrm{J}$ Food Microbiol 177:136-154. https://doi.org/10.1016/j.ijfoodmicro. 2014.02.019

Nakamura H, Takishima T, Kometani T, Yokogoshi H (2009) Psychological stress-reducing effect of chocolate enriched with gamma-aminobutyric acid (GABA) in humans: assessment of stress using heart rate variability and salivary chromogranin A. Int J Food Sci Nutr 60(Suppl 5):106-113. https://doi.org/10.1080/ 09637480802558508

Nawaz M, Wang J, Zhou A et al (2011) Characterization and transfer of antibiotic resistance in lactic acid bacteria from fermented food products. Curr Microbiol 62:1081-1089. https://doi.org/10.1007/ s00284-010-9856-2

Nomura M, Kimoto H, Someya Y, Suzuki I (1999) Novel characteristic for distinguishing Lactococcus lactis subsp. lactis from subsp. cremoris. Int J Syst Bacteriol 49(Pt 1):163-166. https://doi.org/10. 1099/00207713-49-1-163

Nomura M, Kimoto H, Someya Y et al (1998) Production of gammaaminobutyric acid by cheese starters during cheese ripening. J Dairy Sci 81:1486-1491. https://doi.org/10.3168/jds.S0022-0302(98) 75714-5

Park K-B, Oh S-H (2007) Production of yogurt with enhanced levels of gamma-aminobutyric acid and valuable nutrients using lactic acid bacteria and germinated soybean extract. Bioresour Technol 98: 1675-1679. https://doi.org/10.1016/j.biortech.2006.06.006

Salminen S, von Wright A, Morelli L et al (1998) Demonstration of safety of probiotics - a review. Int J Food Microbiol 44:93-106. https:// doi.org/10.1016/S0168-1605(98)00128-7
Sanders JW, Leenhouts K, Burghoorn J et al (1998) A chloride-inducible acid resistance mechanism in Lactococcus lactis and its regulation. Mol Microbiol 27:299-310

Settanni L, Moschetti G (2010) Non-starter lactic acid bacteria used to improve cheese quality and provide health benefits. Food Microbiol 27:691-697. https://doi.org/10.1016/j.fm.2010.05.023

Siragusa S, De Angelis M, Di Cagno R et al (2007) Synthesis of aminobutyric acid by lactic acid bacteria isolated from a variety of Italian cheeses. Appl Environ Microbiol 73:7283-7290. https://doi. org/10.1128/AEM.01064-07

Small PL, Waterman SR (1998) Acid stress, anaerobiosis and gadCB: lessons from Lactococcus lactis and Escherichia coli. Trends Microbiol 6:214-216

Stadler M, Viernstein H (2003) Optimization of a formulation containing viable lactic acid bacteria. Int J Pharm 256:117-122

Steenbergen L, Sellaro R, Stock A-K et al (2015) $\gamma$-Aminobutyric acid (GABA) administration improves action selection processes: a randomised controlled trial. Sci Rep 5:12770. https://doi.org/10. 1038/srep12770

Temmerman R, Pot B, Huys G, Swings J (2003) Identification and antibiotic susceptibility of bacterial isolates from probiotic products. Int J Food Microbiol 81:1-10

Tsai C-C, Lin P-P, Hsieh Y-M (2008) Three Lactobacillus strains from healthy infant stool inhibit enterotoxigenic Escherichia coli grown in vitro. Anaerobe 14:61-67. https://doi.org/10.1016/j.anaerobe. 2007.11.003

Ueno Y, Hayakawa K, Takahashi S, Oda K (1997) Purification and characterization of glutamate decarboxylase from Lactobacillus brevis IFO 12005. Biosci Biotechnol Biochem 61:1168-1171

Wu Q, Shah NP (2016) High $\gamma$-aminobutyric acid production from lactic acid bacteria: emphasis on Lactobacillus brevis as a functional dairy starter. Crit Rev Food Sci Nutr:00-00. https://doi.org/10.1080/ 10408398.2016.1147418

Wu Q, Shah NP (2018) Restoration of GABA production machinery in Lactobacillus brevis by accessible carbohydrates, anaerobiosis and early acidification. Food Microbiol 69:151-158. https://doi.org/10. 1016/j.fm.2017.08.006

Wu Q, Tun HM, Law Y-S et al (2017) Common distribution of gad operon in Lactobacillus brevis and its GadA contributes to efficient GABA synthesis toward cytosolic near-neutral $\mathrm{pH}$. Front Microbiol 8. https://doi.org/10.3389/fmicb.2017.00206

Yokoyama S, Hiramatsu J-I, Hayakawa K (2002) Production of gammaaminobutyric acid from alcohol distillery lees by Lactobacillus brevis IFO-12005. J Biosci Bioeng 93:95-97

Yoto A, Murao S, Motoki M et al (2012) Oral intake of $\gamma$-aminobutyric acid affects mood and activities of central nervous system during stressed condition induced by mental tasks. Amino Acids 43:13311337. https://doi.org/10.1007/s00726-011-1206-6

Yunes RA, Poluektova EU, Dyachkova MS et al (2016) GABA production and structure of gadB/gadC genes in Lactobacillus and Bifidobacterium strains from human microbiota. Anaerobe 42: 197-204. https://doi.org/10.1016/j.anaerobe.2016.10.011

Zhang Y, Song L, Gao Q et al (2012) The two-step biotransformation of monosodium glutamate to GABA by Lactobacillus brevis growing and resting cells. Appl Microbiol Biotechnol 94:1619-1627. https:// doi.org/10.1007/s00253-012-3868-8

Zhao A, Hu X, Pan L, Wang X (2015) Isolation and characterization of a gamma-aminobutyric acid producing strain Lactobacillus buchneri WPZ001 that could efficiently utilize xylose and corncob hydrolysate. Appl Microbiol Biotechnol 99:3191-3200. https://doi.org/10. 1007/s00253-014-6294-2

Publisher's note Springer Nature remains neutral with regard to jurisdictional claims in published maps and institutional affiliations. 